\title{
Удк [7.042:636.7]:75.055(38)(-06/-05)
}

\section{А. Е. Петракова}

\section{Мотив «эмоциональной» собаки в аттической вазописи VI-V вB. до н. э.}

Статья посвящена анализу изображений собаки в визуальной риторике аттических черно- и краснофигурных ваз. Из всех одомашненных древними греками животных собака обладает наиболее выразительным языком тела, а ее роль в жизни человека оправдывает ее присутствие во множестве разнообразных контекстов. Исследуется образ собаки в дошедших до нас античных текстах, производится сопоставление дескриптивной и изобразительной традиций в представлении собаки. Интерпретируется резкое увеличение числа изображений собак в аттической вазописи последней трети VI - первой трети V в. до н. э. и их возможная роль в качестве смыслового элемента вазовой росписи. Выдвигается предположение, что поведение собаки в ряде росписей названного периода дублирует или даже помогает раскрыть суть эмоционального состояния персонажей-людей.

Ключевые слова: аттическая вазопись, изобразительная риторика, иконография собаки, образ собаки в искусстве, собака в древнегреческой литературе, сюжеты древнегреческой вазописи, иконография аттической вазописи, интерпретация изображения

\section{Anna E. Petrakova}

\section{Motive of «emotional» dog in Attic vase-painting of 6 th - 5 th century BC}

The article deals with the analysis of depictions of dogs in visual rhetoric of the Athenian black- and red-figure vase-painting. Among all the domesticated by ancient Greeks animals the dog has the most expressive bodylanguage, while the role of the dog in the life of human society justifies its presence in numerous and variable contexts. The author studies the image of dog in ancient Greek texts, compares the descriptive and the pictorial tradition in the presentation of dogs, interprets increasing of number of Athenian vase-paintings with depictions of dogs at the last third of the 6th - first third of the 5th century BC as well as possible role of the depictions of dogs in the whole system of visual narrative as meaningful rhetoric elements. It is suggested, that the behavior of dogs in some vase-paintings of the period repeats the behavior of the human participants or even helps to understand the essence of the emotional condition of the presented in the composition human beings.

Keywords: Attic vase-painting, visual rhetoric, iconography of dog, image of dog in visual art, dog in ancient Greek texts, subjects of ancient Greek vase-painting, iconography of Attic vase-painting, interpretation of images Dol 10.30725/2619-0303-2018-3-170-177

Статья является авторской переработкой доклада и публикации по нему на английском языке в материалах конференции в г. Грац в 2013 г. [1].

В собрании Государственного Эрмитажа хранится краснофигурный аттический килик инв. Б. 2009 [2, p. 27-29, pl. 17-18; 3, no. 200982], атрибутированный Мастеру Эпидрома [4, кат. 15], позднее отождествленному с ранней фазой Аполлодора [5, р. 25-26], и датированный ок. 500-490 гг. до н. э. Килик декорирован только внутри: в медальоне представлен бородатый мужчина в плаще; левой рукой он опирается на суковатую палку, в правой руке держит зайца. Взгляд мужчины направлен к зайцу и к надписи, которая располагается над ним. Надпись гласит: «Эпидром прекрасен». За мужчиной изображен пес, который проявляет очевидный интерес к зайцу: он поднял правую лапу и делает стойку. В правой части медальона представлены губка, арибалл (флакон для ароматического масла) и стригил (скребок для очистки тела).
Ваза была найдена в 1829 г. в Канино во время раскопок Люсьена Бонапарта, брата Наполеона Бонапарта [6, р. 44-45], и уже тогда изображение было интерпретировано как «охотник с трофеем» [7, p. 125, Nr. 1425; 8, part II, p. 117, Nr. 60]. Той же точки зрения придерживался чуть позже и Теодор Панофка, который интерпретировал мужчину как охотника с атрибутами (заяц - охотничий трофей) [9, S. 6].

В XX в. хранитель и автор каталога краснофигурных аттических ваз в Эрмитаже А. А. Передольская отметила, что заяц - не просто трофей, а может быть и любовным даром, с которым мужчина пришел на палестру к юному возлюбленному [4, с. 22]. Действительно, помимо изображения денег (монеток и кошельков) в качестве платы за любовь, афинские мастера часто рисовали в сценках на вазах петушка или зайчика, которые известны своей любвеобильностью. Такое животное в качестве подарка - изящный намек, выражающий желания дарителя 
по отношению к одаряемому [10, р. 17-18], т. е. бородатый мужчина принес зайчика более молодому юноше, который, как и пристало добропорядочному юноше и гражданину, тренируется на палестре (ведь рядом на стене изображены атрибуты палестрита - губка, арибалл, стригил). Отмечу, что вазописец создал несколько чаш с аналогичной надписью и похожей композицией (в том числе, без зайца) [11, с. 157-163].

Проблемы изобразительной риторики в аттической вазописи занимали отечественных и зарубежных ученых на протяжении всего XX в., а в XXI в. буквально ежегодно появляется по несколько книг и статей на эту тему. Уже в 1939 г. Тальбот Вебстер отметил [12, р. 103-123], что канфар в руке Геракла и ойнохоя в руке Афины, из которой она наливает герою вино в медальоне чаши инв. 2648 из Собрания древностей в Мюнхене [13, S. 64-66, Taf. 41, 3-5; 42, 1-6; 43, 1-4; 3, no. 205230], - это изобразительная метафора взаимоотношений богини-донора и герояреципиента. Ведь Афина постоянно помогает Гераклу и буквально вливает в него силы и разум.

Не можем ли мы аналогичным образом посмотреть и на эрмитажный килик? Заяц уже пойман и никуда не сбежит. Собака делает на него стойку. Вазописец очень старательно изобразил характерное движение пса, при этом нарисовал только две лапы (узнаваемая поза важнее анатомии). Собака выражает свой интерес к зайцу очень живо и откровенно. А вот бородатый поклонник не может выразить свой интерес к юному Эпидрому так же открыто. Это невозможно и в силу формальных особенностей росписи этого времени (в ранней краснофигурной вазописи эмоции на лице и жестикуляция передаются сдержанно), и в силу представлений о том, как стоит изображать добропорядочного гражданина в визуальных искусствах [14]. Могут ли эти собака и заяц быть скрытой изобразительной метафорой, отсылающей зрителя к чувствам, которые бородатый мужчина испытывает к юноше, получающему любовный дар?

Этот вопрос заставил автора настоящей публикации изучить более тысячи произведений аттической вазописи архаики и классики с изображениями собак. Среди представленных на этих вазах реальных и фантастических зверей и птиц собака встречается на удивление часто. Животные (в частности, собаки) предстают на вазах в разных контекстах, которые представляется возможным разделить на четыре группы.

В первую группу можно объединить декоративные изображения, где сюжет отсутствует или сведен к минимуму. Это ряды животных во фри- зах или же одно-два животных, представленные на небольшой вазе. В рядах собаки появляются редко, но, в отличие от других животных (например, пантер, козлов, оленей), они представлены не просто в виде чередующихся элементов, а активно вовлеченными в действо - они охотятся [3, no. 3335] или играют с человеком [3, no. 202330], или занимаются другими делами [3, no. 13220], пусть даже одна и та же группа с участием собаки повторяется на вазе несколько раз. Есть вазы в виде головы собаки [4, кат. 70], а также вазы, для которых изображение собаки целиком или только ее головы является единственным или основным элементом декора, например, в медальоне чаши [3, nos. 13213, 14075, 200832] или на крышке пиксиды [3, nos. 14447, 21189].

Вторая группа - это сцены с повествованием (разнообразные мифологические истории), в которых присутствие животных оправдано самим сюжетом. Без них этот сюжет представлен быть не может, они - необходимый и неотъемлемый элемент иконографии и всей визуальной конструкции. Так, охоту на Калидонского вепря $[3$, nos. 10149, 7876] или смерть Актеона [3, nos. 29150, 6384, 202576, 202595, 206276] было бы крайне сложно визуализировать без собак (редкий пример: [3, no. 5042]). Не будем забывать и собак-чудовищ: трехголовых или трехтелых Кербера [3, nos. 2587, 6835] и Орфа [3, nos. 200080. 301042], а также Сциллу [3, no. 1006059] с ее собачьими головами. Кроме того, собаки являются спутниками и символами богов, например, Гермеса, Артемиды, Гекаты [3, nos. 200986, 23032, 220515], хотя боги легко могут быть представлены и без них.

В третью группу можно выделить эмблемы на щитах. Они бывают разными (звери, птицы, рыбы, насекомые, змеи, чудовища, предметы), в том числе - в виде собак разных пород и в разных позах. Причем разнообразие этих поз весьма велико (гораздо больше, чем у других животных-эмблем): спокойно стоящая на четырех ногах собака, смотрящая вперед; заинтересованная чем-то собака, глядящая назад, вверх или вниз; уверенная в себе собака с хвостом и головой вверх; игривая собака, припавшая на передние лапы [3, nos. 10722, 201035, 200360, 200676, 200731]; собака, стоящая с поднятой передней лапой в позиции стойки и с головой, направленной вперед или назад [3, nos. 202064, 203671, 203841, 203902, 204538, 301894]; сидящая собака, в состоянии спокойствия или заинтересованности [3, no. 13855] и пр. Щиты с такими эмблемами могут быть в руках воинов (включая воинов в «восточной» одежде) [3, no. 203671], Афины [3, nos. 202064, 203841], Ахилла 


\section{А. Е. Петракова}

[3, no. 203902] и др. Есть даже случаи, когда в одной и той же вазовой росписи присутствует собака в качестве эмблемы на щите и собака, стоящая под щитом у ног воина [3, nо 301894]. Собака в данном случае не является неотъемлемой частью изобразительного повествования (ведь эмблем очень много, они разнообразны, также в аттической вазописи представлено очень много щитов вообще без эмблем), но может восприниматься как своеобразное риторическое дополнение к характеристике образа воина, например, намекая на такие качества собаки, как быстрота, неутомимость, желание преследовать врага до последнего и т. д. Именно такие качества мы вычленяем из дескриптивной традиции в дошедших до нас текстах VIII-IV вв. до н. э., о чем будет сказано ниже.

И, наконец, четвертая группа: животные (в частности, собаки), которые представлены в контексте разнообразных нарративных сцен как мифологического, так и бытового характера; они активно вовлечены в повествование или же занимаются своими делами, не обращая внимания на людей. Разнообразие контекстов очень велико, оно не ограничивается лишь охотой [3, nos. 301519, $9301,12089,216378]$. Это игры и прочие способы взаимодействия с собаками [3, nos. 3997, 12840, 16283, 202005, 203991, 203994, 10749]; что-то вроде танца [3, nо. 14139]; собаки, которым предлагают еду или игрушки [3, nos. $5728,8714,11642,13419,207462] ;$ хозяин обнимает, хватает, гладит собаку [3, nos. 11379 , 302837]; собака прыгает на хозяина [3, nos. $10749,12474,202602]$, дает ему лапу [3, no. 8843], кладет на него две лапы [3, no. 302083]; собаки живо реагируют на те или иные объекты (гроздь винограда, герму, зайца и т. п.) или же на след на земле [3, nos. 10227, 12262, 202133, 202230, 202458, 203006, 203243, 203428, 203815, 204399]; собаки воруют еду и несут ее во рту [3, nos. 302860, 302859, 302872, 302889, 302996, 303002], испражняются [3, no. 8843] и пр. Также бывают редкие и необычные контексты: например, собака, которая ловит ежика [3, no. 214330], или собака, которой показывают кошку [3, по. 211392] - как тут не вспомнить картину Яна Стена «Дети обучают кошку танцевать / Урок танца» (1660-е гг., Амстердам, Королевский музей) с аналогичной забавой. Кроме этого, есть много случаев, когда собака как бы провоцирует зрителя повернуть вазу другой стороной, чтобы увидеть всю композицию - ведь она явно реагирует на что-то, нарисованное там: это может быть изображение на противоположной стороне вазы $[3$, nos. 7414, 9575, 301643] или на верхнем ярусе (например, собака, представленная на тулове вазы, смотрит на что-то, изображенное на плечиках вазы) [3, no. 13579].

Помимо сценок, в которых присутствие собаки оправдано действием, в которое она вовлечена, есть также множество примеров как бытовых, так и мифологических сценок с собаками, которые прекрасно могли бы быть представлены и без них. Это подтверждают соответствующие аналогии в афинской вазописи.

Например, на эрмитажной чернофигурной амфоре инв. Б. 168 изображен Приам, испрашивающий у Ахилла тело Гектора [15, кат. 70]. Собака, крадущая кусок мяса или находящаяся под ложем [3, no. 350209], вовсе не является необходимым иконографическим элементом этой сцены. Гораздо чаще в этой сцене вазописцы изображают под ложем тело Гектора (которое занимает под ним все место, не оставляя пространства для каких-либо других элементов) [3, nos. 7276, 14344, 203068, $204333,350427,380848]$ или там вообще пусто [3, nos. 310007, 204333].

Другим примером может служить сцена сражения Геракла с Немейским львом. Присутствие бегущей собаки в этой сцене не является необходимым иконографическим элементом (ср., например: [3, nos. 37, 390, 596, 654, 1014, 1084, 1169, 1297, 1493, 1494, 1596, 1793, 1853, $1969,2197,5695])$. Ее там вообще не должно быть. И в большинстве случаев вазописцы обходятся без нее. Но на чернофигурной амфоре, опубликованной в 1982 г. Эльке Бер [16, Taf. 168; 3, no. 6429], мы видим в левой части композиции собаку, быстро убегающую вместе с юношей (возможно, Иолаем).

И таких примеров мифологических и бытовых сценок довольно много: это сцены прощания пешего воина с семьей перед уходом на войну или встречи воина с семьей [3, nos. 1575, 10722, 10723, 301458, 310336, 310471, 1474, 1480, $1576,5728,5983,7418,8266,9464,13856,23064$, 23083, 200166, 200175, 201654, 201657, 202097, 202133, 202227, 202458, 206596, 213886, 301473, 301894, 302202, 302288]; сцены с колесницами в разных контекстах [3, nos. 10846, 302025, 302062, 302068, 302866, 303413, 1017, 1188, 2976, $3277,3891,6277,6805,8076,8101,13167,14157$, 18449, 23623, 25697, 26140, 200182, 301535, 301805, 301834, 301840, 301907, 302043, 302044, 302051, 302237]; изображения с возлежащими на ложах и пирующими богами или смертными [3, nos. 7648, 10707, 206491, 300837, 302866, 302905, 23667, 43016, 204132, 206435, 301923, 302249, 302330, 302859, 302860]; конные амазонки, восточные воины, фракийцы [3, nos. 14468, 24347, 301780, 302100, 302205, 10725, 11798] и т. п.; 
юноши-всадники (вооруженные и нет) [3, nos. 29, 6810, 302062, 302063, 302064, 302079, 302099, 303174, 320076, 339758, 351217, 2715, 5695, 7419, 14223, 14893, 15752, 24076, 31768]; уроки музыки, сцены с играющими музыкантами или людьми с музыкальными инструментами в руках [3, nos. 200183, 201836, 201872, 202732, 204512, 204984, 206471, 206472, 208422, 211489, 213863, 214094]; беседующие мужчины и юноши [3, nos. 203966, 310487, 320424, 202005, 202868, 202958, 204399, 204493, 204516, 206481, 207586, $275181,302752]$, включая такие сценки, которые могут быть интерпретированы, как сцены ухаживания [3, nos. 301064, 7479, 8573, 9533, 203021, 301624, 302651, 302826, 201962, 202581, 202602] и многие другие контексты (атлеты, любовное преследование, комос, свадебные приготовления и т. п.) [3, nos. 202230, 202886, 302831, 208182, 301898, 302203, 302955, 302956, 203132, 350464, 24456, 24457, 15283, 203223, 204760, 206277, 759, 301145, 4236, 203991, 203994, 205075, 207322, 230826]. Все перечисленные сцены могут быть легко реализованы и без изображения собак. Возникает вопрос: какова функция этих собак, без которых прекрасно можно обойтись в общей системе изобразительного повествования?

Вернемся к статистике. Если мы посмотрим на датировку около тысячи росписей, в которых собаки не являются необходимым элементом в композиции, мы увидим, что их количество резко возрастает в последней четверти VI первой четверти V в. до н. э. Количество аналогичных изображений в период до последней четверти VI в. до н. э. и после первой четверти V в. до н. э. во много раз меньше.

Итак, большинство этих собак не являются необходимым элементом повествования, их присутствие никак не оправдано, они живут своей жизнью в нижней части композиции, иногда люди не обращают на них внимания [3, nos. 29, 1575, 7648, 10598, 10707, 202868, 207322, $300837,301064,301458,301898,302062$, 302063, 302064, 302099, 302100, 302203, 302328]. В других случаях собаки, наоборот, привлекают внимание всех или одного участников сценки [3, nos. 5728, 6810, 15752, 200166, 201962, 202005, 202227, 202230, 203966, 206491, 207462]. Изредка собаки привлекают внимание человека физически [3, nos. 14157, 23083, 200183, 302083].

В периоды за пределами выделенного хронологического пика, собаки в большинстве случаев участвуют в мифологической или обычной охоте (например: [3, no. 217908]), их присутствие в качестве необязательного элемента повествовательной конструкции встречается редко (например: [3, no. 230433]).
В чем же причина того, что количество изображений собак, без которых вполне можно обойтись, резко возросло в афинской вазописи конца VI - начала V в. до н. э. ? Безусловно, вазопись чутко реагировала на изменения как в политической жизни, так и в повседневной, рисунки на вазах служили целям рекламы, пропаганды, популяризации той или иной идеи или явления. Рассуждение о вазописи как своеобразном «масс медиа» уже стало «общим местом» научных трудов об аттических вазах (например: [17; 18]).

Но собаки не были чем-то новым в Афинах архаики и классики! Не были они и тем, что нуждалось в «пропаганде» или «популяризации». Что же собой представляет собака в конструкции визуального нарратива и чем она отличается от других животных? Во-первых, из всех одомашненных греческих животных именно собака обладает наиболее богатым языком тела для выражения своих эмоций (гораздо более богатым, чем, например, конь). Во-вторых, язык собачей коммуникации универсален - вне зависимости от столетия или страны, в которой проживает собака. В то время как человеческий язык жестов не универсален: один и тот же жест в разных странах и в разные эпохи может означать очень разные вещи. В-третьих, даже если собака представлена схематично, все равно язык ее тела (даже без участия мимики), достаточно богат, чтобы передать нужную эмоцию, в силу ее физиологических особенностей.

Обратимся к дошедшим до нас античным текстам, датируемым VIII-IV вв. до н. э., т. е. более или менее современным тем памятникам вазописи, которые рассматриваются в статье. В этих текстах собаки неоднократно упоминаются как участники охоты, как спутники благородных мужей и юношей («Шел не один он. За ним две резвых собаки бежали», Гомер, «Одиссея», XX, 145-146), как домашние питомцы («Меня, как собачонку, в доме заперли», Эсхил, «Хоэфоры», 445), как защитники собственности (дома, стада, двора), атакующие чужаков, громко лая (неоднократно упомянуто в «Одиссее», «Илиаде» и др.). Собаки разрывают на куски трупы, вцепляются врагу в печень (неоднократно упомянуто у Гомера, Эсхила, Софокла и пр.), а еще «вьются обычно / Возле стола у господ... их для роскоши держат» (Гомер, «Одиссея», XVII, 317-360).

«Собака / пес / сука» - распространенное ругательство, применяемое для метафорической характеристики человека и его поведения: наглый / бесстыдный / бессердечный и так далее пес / собака: «Да, нахалка, собака бесстыжая» (Гомер, «Одиссея», XIX, 90-91), «Через рабынь, бессердечных собак» (Гомер, «Одиссея», XIX, 


\section{А. Е. Петракова}

154), «Он, хоть и нагл, как пес» (Гомер, «Илиада», IX, 375), «Бессовестные собаки, которые не уважают богов» (Эсхил, Просительницы, 757-759). И, наоборот - комплимент, например, для хорошей жены - «верная собака»: «Ему жена - собака в доме верная: / Хозяину покорна и врагу страшна» (Эсхил, «Агамемнон», 610). Получается, что собака, в понимании греков, - существо «амбивалентное», обладающее как положительными, так и отрицательными качествами, и даже характеризуемое как «коварное создание», которое может поменять свое настроение очень быстро. Лучшее описание, на наш взгляд, дает Гесиод: «Сторожем пес беспощадный и страшный сидит перед входом / С злою, коварной повадкой: встречает он всех приходящих, / Мягко виляя хвостом, шевеля добродушно ушами. / Выйти ж назад никому не дает, но, наметясь, хватает / И пожирает...» (Гесиод, «Теогония», 765-775).

Замечу, что в процитированных текстах (как и во множестве оставшихся за пределами этой статьи), человек постоянно сопоставляется с собакой. Это и косвенные, и очень прямые сопоставления, которые выражаются не только в ругательствах или в похвале с использованием слова «собака, пес», но и в сравнении поведения человека и собаки в той или иной ситуации. Например: «Как над щенятами стоя бессильными, грозно собака / На человека чужого рычит и готова кусаться» (Гомер, «Одиссея», ХX, 12-15), так же рычало сердце Одиссея, размышлявшего о женихах Пенелопы, разорявших его дом и хозяйство.

Такое же сопоставление, но уже не вербальное, а визуальное, мы, вне всяких сомнений, видим и на аттических вазах. Например, на кувшинчике инв. І. 1956. 7. 5 из Королевского музея в Лейдене [19, pl. 188, 3-4; 3, no. 44297] представлены ребенок и собака, ползущие к столу в абсолютно одинаковых позах: художник явно сопоставляет их размеры, позы, поведение. На амфоре, декорированной в технике Сикса инв. F 114 из Лувра [3, nо. 302837] на шейке представлена обнаженная женщина, нюхающая цветок, в то время как собака нюхает ее пальцы, расположенные у ее лона: очевидно, каждый из участников сцены наслаждается ароматом. В обоих случаях сопоставление наводит на мысль о своеобразной иронии вазописца. Наилучшим примером такого сопоставления является краснофигурный килик из коллекции Нельсона Банкера Ханта [3, no. 8843]: на одной из внешних сторон килика изображен пес, который дает лапу юноше, в медальоне же аналогичный пес кусает аналогичного юношу. Здесь очевидно визуальное сопоставление невоспитанных собак и невоспитанных юношей
[20, р. 96-97], подобное тому, как в процитированных текстах положительные и отрицательные качества собак сопоставляются с аналогичными качествами мужчин и женщин.

В дошедших до нас античных текстах старательно и подробно описаны черты поведения собак, их телесный язык. Они подходят, «приветно виляя большими хвостами, / Как пред хозяином, зная, что лакомый кус попадет им, / Машут хвостами собаки, когда от обеда идет он» (Гомер, «Одиссея», Х, 215-220), или: «залаять не смея, в сторону с визгом мчатся» (Гомер, «Одиссея», XVI, 162-163). Ну, и, конечно, самое трогательное - когда Одиссея узнает его старый пес: «Пес, лежавший близ двери, вдруг голову поднял и уши, / ...Там он на куче лежал, собачьими вшами покрытый. / Только почувствовал близость хозяина пес, как сейчас же / Оба уха прижал к голове, хвостом повилявши. / Ближе, однако, не мог подползти к своему господину» (Гомер, «Одиссея», XVII, 317-360). Получается, что древнегреческие владельцы собак очень внимательны к нюансам их поведения. И все эти особенности - разные позы, реакции, настроения и т. п. общеизвестны, являются «общим местом», понятным слушателям «Илиады», «Одиссеи», зрителям пьес Эсхила, Софокла, Еврипида. Эти же нюансы поведения в изобилии представлены на аттических черно- и краснофигурных вазах (при этом еще изображены собаки разных пород, размеров и разного пола).

Конечно, собаки появляются на вазах не только как участники действа, но и как атрибуты. Например, атрибут охотника (включая охотников - персонажей мифов) [3, nos. 206356, 207669, 214049, 214151, 301203] или символ статуса и достатка - собак ведь надо кормить (особенно, когда среди возлежащих на клине участников пира представлено несколько собак, ворующих или просто поглощающих мясо) [3, nos. 7648, 10707].

Но, исходя из всего вышесказанного, мы можем предположить, что введение собак в композиции этим не ограничивается. Афинская вазопись дает нам гораздо более широкий, чем тексты, спектр ситуаций с участием собак, нюансов их поведения, эмоциональных реакций (показанных иногда не только при помощи языка тел, но также и мимикой на морде) [3, nos. 1575, 9301, 302099, 303413, 200166]. Если суммировать все сказанное и вспомнить о приведенной выше статистике, можно предположить, что феномен резкого увеличения количества изображений собак в композициях на вазах конца VI - начала V в. в тех случаях, когда сцена, может быть изо- 


\section{Мотив «эмоциональной» собаки в аттической вазописи VI-V вв. до н. э.}

бражена и без собаки, объясняется желанием вазописца «оживить» сценку и добавить визуального выражения чувств.

В это время вазописцы обычно изображали фигуры в один ряд. На разных уровнях, как на знаменитом кратере Мастера Ниобид [3, no. 206954], персонажей стали располагать позже. Получается, что во многих композициях (особенно в тех, где представлены всадники на конях, колесницы или возлежащие на ложах участники пира, а располагаются эти композиции на больших вазах - амфорах, кратерах, гидриях) внизу было бы слишком пусто, как, например, на эрмитажном кратере инв. Б. 1522 [21, кат. 52; 3 , no. 320269]. И собаки, помимо того, что они, безусловно, являются «атрибутами» знатных и состоятельных участников сценки, также позволяют не только «оживить», но и физически заполнить пустое пространство.

Они делают сценку менее «пустой» и более «жизненной» благодаря как их разнообразным позам, занятиям, так и их расположению в общей композиции. Они могут смотреть на людей снизу-вверx [3, nos. 759, 6810, 7648, 10598, 203966, 206491, 201654, 202005, 202133, 302099, 202230, 302237] или как бы за пределы изобразительного поля, будто реагируя на что-то, чего мы не видим [3, nos. 1188 , 6277, 6429, 8101, 10725, 11798, 23623, 25697, 302203, 302121], или они могут быть как бы «срезанными» рамкой, намекая на то, что мы видим лишь часть большего действа [3, nos. $6805,13307]$. Они также могут заниматься своими делами, пока люди занимаются своими. В любом случае, они делают композиции более интересными. Ведь, кроме наиболее богатого языка тела из всех одомашненных греками животных, собаки имеют и наиболее широкий спектр «предлогов» находится рядом с человеком как в интерьере, так и за пределами дома.

Помимо этого, нужно обратить внимание на эмоции, которые выражают собаки. В афинской вазописи последней четверти VI - первой четверти $V$ в. до н. э. они зачастую выглядят гораздо более эмоциональными, чем их хозяева. Они выражают эмоции при помощи не только тел, но и мимики, в то время как мимика и жесты людей на вазах этого же времени гораздо более скованы - это обусловлено и навыками художников, и представлениями о приличиях. До середины VI в. до н. э. афинские вазописцы не были особенно заинтересованы в передаче эмоциональных нюансов. B конце VI - начале V в. до н. э. даже при изображении битвы или сцены любви (т. е. явно очень эмоционально насыщенной ситуации) лица персонажей не искажались эмоциями: глаз передавался фронтально на лице в профиль, губы - сомкнутыми и т. п. Приоткрытые губы, направленный взгляд и прочие мимические искажения лиц появились и получили распространение в вазописи позже. В медальоне чаши инв. 48 из Замкового музея в Готе [3, no. 200100] представлена пара любовников, их лица не очень-то эмоциональны, зато в левой части композиции мы видим зайчика, сидящего в клетке, и собаку, живо реагирующую на него. Юноша постарше сжал в объятиях своего более молодого возлюбленного, который никуда от него не убежит - так же, как не убежит от собаки зайчик, ведь он уже пойман и посажен в клетку.

Как видно из текстов и рисунков на вазах, греки хорошо знали поведение, повадки и язык тела собак, через который визуализируется их настроение. И, возможно, в некоторых росписях собака - это нечто большее, чем просто атрибут или формальный элемент композиции, нужный для уравновешивания другого элемента. Полагаю, что в некоторых случаях мы можем воспринимать изображения собак как риторические фигуры или «скрытые послания» зрителю. Например, на чернофигурной амфоре инв. 1570 из Собрания древностей в Мюнхене [3, no. 7500] собака под всадником отчетливо демонстрирует страх, в то время как юноша, как и приличествует юноше-гражданину-воину, транслирует спокойствие. На краснофигурном стамносе из Национального музея в Копенгагене [3, no. 202230] юноша протягивает кошелек с деньгами одной женщине, в то время как другая дама, с зеркалом, пытается привлечь его внимание. Собака между ними явно демонстрирует интерес к юноше - не помогает ли она даме с зеркалом в передаче ее чувств по отношению к юноше? На чернофигурной амфоре, однажды выставленной на торги Sotheby's [3, no. 23083], уходящий на войну мужчина глядит на старика-отца, все прилично... но собака за его спиной засунула морду между ног стоящей справа женщины и, по-видимому, блаженно вдыхает ароматы. Как знать, не намек ли это вазописца на некие скрытые мысли воина, который долго будет лишен женского общества (о чем и он думает на самом деле, пока, как и положено, учтиво прощается со стариком-отцом)? На одной из сторон оноса (эпинетрона) из Королевского музея в Лейдене [22, p. 68. 1-5; 3, no. 1157] добропорядочная, закутанная в одежду женщина сидит с корзиной для рукоделия между двумя мужчинами. Они оба смотрят на нее, а она смотрит в пол, как и положено приличной греческой женщине. Но под ее стулом мы видим маленькую со- 


\section{А. Е. Петракова}

бачку с задранным хвостом. В Корпус вазорум Лейденского музея она описана как «маленькая лающая собачка с огромным пушистым хвостом» $[22$, р. 20]. Однако, внимательно изучив позу собачки, мы приходим к выводу, что своей позой она не выражает агрессию, а приглашает к игре; она не агрессивно лает на чужака, а припала на передние лапы, как делает собака, которая заигрывает с человеком или другой собакой, а задранный кверху хвост может также свидетельствовать о готовности к любовным играм. Ваза, на которой выполнена роспись - это наколенник, который использовали женщины во время рукоделия. Возможно, мужчина-вазописец заложил в роспись некую скрытую иронию по поводу добропорядочных женщин: даже самые скромные из них всегда готовы к любовным играм с мужчинами. Во многих античных текстах (например, в комедиях Аристофана) об этом говорится очень часто, прямо и недвусмысленно.

Возвращаясь к эрмитажному килику и некоторым другим вазам этого же периода (например: [3, no. 200100], мы можем предположить, что в этом и аналогичных случаях открыто проявляющие свои эмоции собаки могут рассматриваться как своеобразные помощники людей, нужные для выражения чувств или для привлечения зрительского внимания. Кстати, собака, привлекающая зрительское внимание к чему-либо, нередко встречается и в европейской живописи XVII-XVIII вв. Примерами могут служить картина «Самсон и Далила» Яна Стена (1660-е гг., Кельн, Музей Вальрафа-Рихарца), на которой собака вцепилась в подол платья Далилы, его же «Веселое общество» (ок. 1660 г., Будапешт, Музей изящных искусств), где под табуретом прилично одетой женщины (держащей в руке сосуд, из которого пьет мальчик) изображена припавшая на передние лапы игривая собачка с задранным кверху хвостом, или «Любовное письмо» Ж.-О. Фрагонара (начало 1770-х гг., Нью-Йорк, Музей Метрополитен), где собачка, расположенная рядом с женщиной, читающей любовное письмо, живо реагирует на потенциального зрителя, который как будто бы застал женщину врасплох. Если мы вспомним ругательства из древнегреческих текстов, амбивалентность собаки и частое сравнение в этих текстах собак с мужчинами и женщинами, добавим к этому богатый и универсальный язык собачьего тела - предположение о том, что аттические вазописцы архаики могли намеренно вводить собак в свои композиции в качестве риторических фигур (метафоры и повтора), не покажется фантастическим.

\section{Список литературы}

1. Petrakova A. Emotional dog in Attic vase-painting: symbolical aspect and instrumental narrative function // Фuta Kaı Zwıa: Pflanzen und Tiere auf griech. Vasen: Akten des Symp., Sept. 26-28, 2013, Graz, Karl-Franz Univ., CVA Österreich, Beiheft 2. Graz: Verl. der Österreich. Akad. der Wissenschaften, 2015. S. 291-298.

2. Petrakova A. Corpus Vasorum Antiquorum, Russia, fasc. XII, The State Hermitage Museum, fasc. V. Roma: L'erma di Bretschneider, 2007. URL: http:// academia.edu (дата обращения: 17.07.2018).

3. Beazley Archive Pottery Database. URL: http: // beazley. ox. ac. uk (дата обращения: 17.07.2018).

4. Передольская А. А. Краснофигурные аттические вазы в Эрмитаже: каталог. Ленинград: Совет. художник, 1967. 404 c.

5. Williams D. Corpus Vasorum Antiquorum, Great Britain, fasc. 17, The British Museum, fasc. 9, London: The Trustees of the British Museum, British Museum Press, $1993.80 \mathrm{p}$.

6. Petrakova A. Canino vases in the State Hermitage Museum: history of purchasing // The Canino connections: proc. of the conf., Leiden, 27-28 Jan. 2015, The Canino Connections - Lucien Bonaparte and the Trade in Greek Vases in the 19th Century. Leiden: Sidestone Press, 2017. P. 43-52.

7. Muséum étrusque de Lucien Bonaparte, prince de Canino, fouilles de 1828 à 1829. Viterbe: Chez C. Tosoni, 1829. $211 \mathrm{p}$.

8. Catalogo di scelte antichita etrusche, trovate negli scavi del Principe de Canino 1828-29: Presso Camillo Tosoni, Viterbo, 1829. $185 \mathrm{p}$.

9. Panofka Th. Die griechischen Eigennamen mit Kalos im Zusammenhang mit dem Bilderschmuck auf bemalten Vasen. Berlin: Gedruckt in der Druckerei der König. Akad. der Wissenschaften, 1850. URL: https: // books.google.ru (дата обращения: 17.07.2018).

10. Sutton R. F., Pornography and persuasion on Attic pottery // Pornography and representation in Greece and Rome / ed. by A. Richlin. New York, Oxford: Oxford Univ. Press, 1992. P. 3-35.

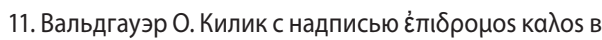
Эрмитаже // Изв. Рос. акад. истории материал. культуры. Санкт-Петербург, 1921. Т. 1. С. 157-163.

12. Webster T. B. L. Tondo composition in archaic and classical Greek art // J. of the Hellenic studies. 1939. Vol. 49. P. 103-123.

13. Pfisterer-Haas S. Corpus Vasorum Antiquorum. Deutschland. Bd. 88. München, Antikensammlungen, ehemals Museum Antiker Kleinkunst. Bd. 16. Attisch Rotfigurige Schalen. München: C. H. Beck, 2010. 92 p.

14. Not the classical ideal: athens and the construction of the other in Greek art / ed. by B. Cohen. Leiden; Boston: Brill, 2000. 559 p.

15. Шлиман. Петербург. Троя: кат. выст. в Гос. Эрмитаже, Санкт-Петербург, 19 июня - 18 окт. 1998 г. / Гос. Эрмитаж; авт. ст.: Е. Б. Ананьич и др. Санкт-Петербург: Славия, 1998. $266 \mathrm{c.}$ 


\section{Мотив «эмоциональной» собаки в аттической вазописи VI-V вв. до н. э.}

16. Böhr E. Der Schaukelmaler. Mainz am Rhein: Philipp von Zabern, 1982. XIII, 146 S.

17. Shapiro H. A. Art and Cult under the Tyrants in Athens. Mainz am Rhein: Philipp von Zabern, 1989. XIII, 194 S.

18. Stansbury-O'Donnell M. Vase painting, gender, and social identity in archaic Athens. Cambridge: Cambridge Univ. Press, 2006. XIV, $316 \mathrm{p}$

19. Vos M. F. Corpus Vasorum Antiquorum, The Netherlands fasc. 7, Leiden, Rijksmuseum van Oudheden, fasc. 4. Leiden: E. J. Brill, 1991. 99 S.

20. Constructions of childhood in ancient Greece and Italy / ed. by A. Cohen, J. B. Rutter. Princeton, New Jersey: The Amer. School of Classical Studies at Athens, 2007. XXIV, 429 p. (Hesperia Supplementum; vol. 41).

21. Горбунова К. С. Чернофигурные аттические вазы в Эрмитаже: каталог. Ленинград: Искусство, 1983. 223 с.

22. Vos M. F. Corpus Vasorum Antiquorum, The Netherlands fasc. 4, Leiden, Rijksmuseum van Oudheden, fasc. 2. Attic Black-Figured Vases. Leiden: E. J. Brill, 1978. 54 p.

\section{References}

1. Petrakova A. Emotional dog in Attic vase-painting: symbolical aspect and instrumental narrative function. Фuta Kaı Zwı: Pflanzen und Tiere auf griech. Vasen: Akten des Symp., Sept. 26-28, 2013, Graz, Karl-Franz Univ., CVA Österreich, Beiheft 2. Graz: Verl. der Österreich. Akad. der Wissenschaften, 2015. 291-298.

2. Petrakova A. Corpus Vasorum Antiquorum, Russia, fasc. XII, The State Hermitage Museum, fasc. V. Roma: L'erma di Bretschneider, 2007. URL: http:// academia.edu (accessed: July 17. 2018).

3. Beazley Archive Pottery Database. URL: http: // beazley. ox. ac. uk (accessed: July 17. 2018).

4. Peredolskaya A. A. Red-figured attic vases in Hermitage: catalogue. Leningrad: Sovetskii khudozhnik, 1967. 404 (in Russ.).

5. Williams D. Corpus Vasorum Antiquorum, Great Britain, fasc. 17, The British Museum, fasc. 9, London: The Trustees of the British Museum, British Museum Press, 1993. 80.

6. Petrakova A. Canino vases in the State Hermitage Museum: history of purchasing. The Canino connections: proc. of the conf., Leiden, 27-28 Jan. 2015, The Canino Connections Lucien Bonaparte and the Trade in Greek Vases in the 19th Century. Leiden: Sidestone Press, 2017. 43-52.

7. Muséum étrusque de Lucien Bonaparte, prince de Canino, fouilles de 1828 à 1829. Viterbe: Chez C. Tosoni, 1829. 211.
8. Catalogo di scelte antichita etrusche, trovate negli scavi del Principe de Canino 1828-29: Presso Camillo Tosoni, Viterbo, 1829. 185.

9. Panofka Th. Die griechischen Eigennamen mit Kalos im Zusammenhang mit dem Bilderschmuck auf bemalten Vasen. Berlin: Gedruckt in der Druckerei der König. Akad. der Wissenschaften, 1850. URL: https: // books.google.ru (accessed: July 17. 2018).

10. Sutton R. F. Pornography and persuasion on Attic pottery. Richlin A. (ed.) Pornography and representation in Greece and Rome. New York, Oxford: Oxford Univ. Press, 1992. 3-35.

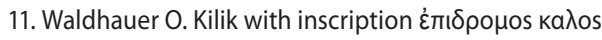
in Hermitage. News of Russ. Acad. of History of Material Culture. Saint Petersburg, 1921. 1, 157-163 (in Russ.).

12. Webster T. B. L. Tondo composition in archaic and classical Greek art. J. of the Hellenic studies. 1939. 49, 103-123.

13. Pfisterer-Haas S. Corpus Vasorum Antiquorum. Deutschland. Bd. 88. München, Antikensammlungen, ehemals Museum Antiker Kleinkunst. Bd. 16. Attisch Rotfigurige Schalen. München: C. H. Beck, 2010. 92.

14. Cohen B. (ed.) Not the classical ideal: athens and the construction of the other in Greek art Leiden; Boston: Brill, 2000. 559 .

15. Anan'ich E. B. etc. (author of article) Schliemann. Petersburg. Troy: exhibition catalogue in Hermitage Museum, Saint Petersburg, June 19 - Oct. 181998 / State Hermitage Museum. Saint Petersburg: Slaviya, 1998. 266 (in Russ.).

16. Böhr E. Der Schaukelmaler. Mainz am Rhein: Philipp von Zabern, 1982. XIII, 146.

17. Shapiro H. A. Art and Cult under the Tyrants in Athens. Mainz am Rhein: Philipp von Zabern, 1989. XIII, 194.

18. Stansbury-O'Donnell M. Vase painting, gender, and social identity in archaic Athens. Cambridge: Cambridge Univ. Press, 2006. XIV, 316.

19. Vos M. F. Corpus Vasorum Antiquorum, The Netherlands fasc. 7, Leiden, Rijksmuseum van Oudheden, fasc. 4. Leiden: E. J. Brill, 1991. 99.

20. Cohen A. (ed.), Rutter J. B. (ed.) Constructions of childhood in ancient Greece and Italy. Princeton, New Jersey: The Amer. School of Classical Studies at Athens, 2007. XXIV, 429 (Hesperia Supplementum; 41).

21. Gorbunova K. S. Attic black-figure vases in Hermitage: catalogue. Leningrad: Iskusstvo, 1983. 223 (in Russ.).

22. Vos M. F. Corpus Vasorum Antiquorum, The Netherlands fasc. 4, Leiden, Rijksmuseum van Oudheden, fasc. 2. Attic Black-Figured Vases. Leiden: E. J. Brill, 1978. 54. 